\title{
Protein $\mathrm{C}$ activation on endothelial cells by prothrombin activation products generated in situ: meizothrombin is a better protein $\mathrm{C}$ activator than $\alpha$-thrombin
}

\author{
Tilman M. HACKENG ${ }_{\dagger}^{\star}$, Guido TANS $\uparrow$, Stefan J. KOPPELMAN*, Philip G. DE GROOT*, Jan ROSING $\dagger$ and Bonno N. BOUMA* \\ *Department of Haematology, University Hospital Utrecht, P.0. Box 85500, 3508 GA Utrecht, The Netherlands, and †Department of Biochemistry, University of Limburg, \\ P.0. Box 616, 6200 MD Maastricht, The Netherlands
}

\begin{abstract}
The conversion of protein $\mathrm{C}$ into activated protein $\mathrm{C}$ (APC) by the thrombin-thrombomodulin complex on the surface of endothelial cells initiates an essential negative feedback reaction on blood coagulation. APC, together with its non-enzymic cofactor protein $\mathrm{S}$, inactivates factors $\mathrm{Va}$ and VIIIa, the non-enzymic protein cofactors of the prothrombinase and intrinsic tenase complex, by proteolytic degradation. In this study we report that prothrombin activation products, generated by the prothrombinase complex on the surface of quiescent endothelial cells, are able to activate protein $\mathrm{C}$. Subsequent inactivation of factor $\mathrm{Va}$ by the APC that was formed decreased the rate of prothrombin activation, thus demonstrating in vitro the negative feedback loop on coagulation factor activation. The anticoagulant feedback reaction of APC on the prothrombinase complex was stimulated 3-4-fold by the addition of protein $\mathrm{S}$ but not by thrombin-cleaved protein $\mathrm{S}$ or by protein $\mathrm{S}$ complexed with $\mathrm{C} 4 \mathrm{~b}-$ binding protein. Stimulation of endothelial cells with $50 \mathrm{pM}$ tumour necrosis factor (TNF) or $500 \mathrm{pM}$ interleukin 1 (IL-1) resulted in a $70 \%$ decrease in activation of protein $\mathrm{C}$ by exogenously added $\alpha$-thrombin, which seemed to be due to
\end{abstract}

down-regulation of thrombomodulin activity on the surface of endothelial cells. However, when prothrombin activation products generated in situ were allowed to activate protein C, stimulation of endothelial cells with TNF and IL-1 resulted in only a $25 \%$ decrease in activation of protein C. Stimulation with TNF or IL-1 did not affect the ability of endothelial cells to support prothrombinase activity. We investigated whether the differences in extent of protein $\mathrm{C}$ activation by exogenously added $\alpha$-thrombin and by prothrombin activation products generated in situ were due to meizothrombin formed during prothrombin activation. Previous reports from our groups revealed that meizothrombin is generated as a transient intermediate during prothrombin activation on phospholipid vesicles and endothelial cells. Here we show that meizothrombin is at least a 6-fold better activator of protein $\mathrm{C}$ on the surface of endothelial cells than is $\alpha$-thrombin. These results demonstrate that meizothrombin, formed during the initial phase of prothrombin activation, efficiently down-regulates both its own formation and that of thrombin.

\section{INTRODUCTION}

Protein $\mathrm{C}$ is a vitamin $\mathrm{K}$-dependent glycoprotein involved in the regulation of blood coagulation. Protein $\mathrm{C}$ is converted into activated protein $\mathrm{C}$ (APC) by thrombomodulin (TM)-bound thrombin [1]. APC expresses its anticoagulant action by inactivating the activated coagulation cofactors Va [2-4] and VIIIa [5-7] in a $\mathrm{Ca}^{2+}$ - and phospholipid-dependent manner. APC cleaves human factor Va first rapidly at $\mathrm{Arg}^{506}$, followed by a slow cleavage at $\mathrm{Arg}^{306}$ and $\mathrm{Arg}^{679}$ [8-10], and cleaves human factor VIIIa first rapidly at $\mathrm{Arg}^{562}$, followed by a slow cleavage at $\mathrm{Arg}^{336}$ [11,12].

In the negative feedback reaction APC is assisted by the nonenzymic vitamin $\mathrm{K}$-dependent cofactor, protein S. Protein S exerts its anticoagulant cofactor activity by increasing the affinity of APC for phospholipid membranes [13] and by stimulating the cleavage at $\mathrm{Arg}^{306}$ in factor Va by APC up to 20-fold [14].

Protein S has APC-independent anticoagulant activity by interacting directly with factor $\mathrm{Va}$ and factor $\mathrm{Xa}$, causing inhibition of prothrombinase activity [15-18].

The physiological importance of the protein $\mathrm{C}$ pathway is emphasized by the clinical manifestations that occur in the absence of protein $\mathrm{C}$ or $\mathrm{S}$. A deficiency in either protein $\mathrm{C}$ or protein $\mathrm{S}$ is the cause of thrombophilia in $10 \%$ of all thrombophilic patients [19].

In addition the protein $\mathrm{C}$ pathway seems to be involved in the response of the vascular endothelium to inflammation and sepsis. Bacterial lipopolysaccharides invading the bloodstream cause the release of cytokines such as interleukin (IL)-1, IL-4, IL-6, IL8 and tumour necrosis factor (TNF). Studies in vitro showed that lipopolysaccharides, IL-1 and TNF increase the procoagulant activity of the endothelium by induction of the surface expression of tissue factor, and by inhibition of protein $\mathrm{C}$ activation via down-regulation of TM [20-25]. Taylor et al. [26] confirmed the importance of the protein $\mathrm{C}$ pathway by using a sepsis model in baboons in which APC infusion protected against lethal doses of Escherichia coli. Inhibition of protein $\mathrm{C}$ activation or protein $\mathrm{S}$ cofactor activity resulted in a lethal response to a sublethal dose of $E$. coli [26-28]. However, when coagulation was inhibited in animal models of Gram-negative sepsis with heparin [29], anti(tissue factor) antibodies [30] or active-site-blocked factor Xa [31], the development of disseminated intravascular coagulation (DIC) was prevented, but not the shock response. More recently, an endothelial cell receptor for protein C/APC was discovered

Abbreviations used: APC, activated protein C; HUVEC, human umbilical vein endothelial cell; I2581, N-dansyl-( $p$-guanidino)phenylalanine piperidine hydrochloride; IL, interleukin; S2366, L-pyro-Glu-Pro-Arg-p-nitroaniline hydrochloride; S2238, D-Phe-(pipecolyl)-Arg-p-nitroaniline hydrochloride; S2222, benzoyl-Ile-Glu-( $\gamma$-OR)-Gly-Arg- $p$-nitroaniline hydrochloride; TM, thrombomodulin; TNF, tumour necrosis factor.

* To whom correspondence should be addressed. Present address: Departments of Molecular and Experimental Medicine and Vascular Biology, SBR5, The Scripps Research Institute, 10666 North Torrey Pines Road, La Jolla, CA 92037, U.S.A. 
that could be down-regulated with TNF in a similar way to that with TM [32]. These observations establish that the protein $\mathrm{C}$ pathway not only is involved in the down-regulation of coagulation but also plays an important role in inflammation and sepsis. Here we present a study on the activation of the protein $\mathrm{C}$ pathway on the surface of human umbilical vein endothelial cells (HUVECs) by locally generated prothrombin activation products (i.e. $\alpha$-thrombin and meizothrombin) and the regulation of this process by the inflammation mediators TNF and IL-1.

\section{EXPERIMENTAL}

\section{Materials}

Human prothrombin complex concentrate was a gift from Dr. J. Over (Central Laboratory of the Netherlands Red Cross Blood Transfusion Services, Amsterdam, The Netherlands). Human $\alpha$ thrombin, the protein $\mathrm{C}$ activator purified from the venom of Agkistrodon contortrix contortrix, and anti-(A. contortrix contortrix snake venom) antibodies were gifts from Dr. W. Kisiel (Department of Pathology, University of New Mexico, Albuquerque, NM, U.S.A.). Recombinant desulphato-hirudin (12000 units/mg; 1 unit inhibits 1 unit of thrombin) was a gift from Dr. R. Wallis (Ciba-Geigy, Horsham, W. Sussex, U.K.). IL-1 was a gift from Dr. L. Aarden (Central Laboratory of the Netherlands Red Cross Blood Transfusion Service). IL-4 was obtained from R\&D Systems (Minneapolis, MN, U.S.A.), TNF was provided by Dr. P. Lomedico (Hoffmann-LaRoche, Nutley, NJ, U.S.A.). Goat anti-(rabbit TM) antibodies were a gift from Dr. K. Preissner (Max-Planck-Gesellschaft, Bad Nauheim, Germany). CNBr-activated Sepharose CL-4B and PD-10 disposable desalting columns were purchased from Pharmacia (Uppsala, Sweden). $N$-Dansyl-( $p$-guanidino)phenylalanine piperidine hydrochloride (I2581) and the chromogenic substrates D-Phe-(pipecolyl)-Arg$p$-nitroaniline hydrochloride (S2238), benzoyl-Ile-Glu-( $\gamma$-OR)Gly-Arg-p-nitroaniline hydrochloride (S2222) and L-pyro-GluPro-Arg- $p$-nitroaniline hydrochloride (S2366) were purchased from Chromogenix (Mölndal, Sweden). Immobilon-P poly(vinylidene difluoride) membranes were obtained from Millipore Corporation (Bedford, MA, U.S.A.). BSA and 3,3-diaminobenzidine tetrahydrochloride were obtained from Sigma Chemical Co. (St. Louis, MO, U.S.A.). Culture plastics and 96well high-binding plates were obtained from Nunc (Rashide, Denmark), except for 96-well strip plates, which were purchased from Costar (Cambridge, MA, U.S.A.). Other tissue culture supplies (media, antibiotics and trypsin) were products from Gibco Biocult (Paisley, Scotland, U.K.). Polyclonal rabbit antibodies against factor $\mathrm{V}$ and peroxidase-conjugated rabbit antibodies against protein $\mathrm{S}$ were obtained from DAKO (Glostrup, Denmark).

\section{Proteins}

Human protein $\mathrm{S}$ and prothrombin were purified as described in [33]. Factor $\mathrm{X}$ and protein $\mathrm{C}$ were purified as previously described [34]. C4b-binding protein was purified as described in [35]. Factor $\mathrm{V}$ was purified as described in [36] with minor modifications [17]. Factor VII was purified as described in [37]. Activation of factors $\mathrm{V}$ and $\mathrm{X}$ and cleavage of protein $\mathrm{S}$ were performed as described previously [17]. $\operatorname{Arg}^{155} \rightarrow$ Ala-meizothrombin was prepared as described in [38].

\section{Protein C activation}

Protein $\mathrm{C}$ was activated by incubation with the purified protein $\mathrm{C}$ activator from the venom from $A$. contortrix contortrix at a concentration of 100:1 (w/w) at $37^{\circ} \mathrm{C}$. After the completion of protein $\mathrm{C}$ activation (determined with $\mathrm{S} 2366$ ), antibodies against the venom activator were added, and the incubation continued for $15 \mathrm{~min}$ before the reaction mixture was passed over a protein $\mathrm{G}$ column. APC eluted in the effluent and was analysed by SDS/PAGE [4-15\% (w/v) gels]. A doublet at $60 \mathrm{kDa}$ under non-reducing conditions and a doublet at $42 \mathrm{kDa}$ (heavy chain) together with a single band at $18 \mathrm{kDa}$ (light chain) under reducing conditions were observed. Less than $10 \%$ single-chain protein C was detected as a doublet at $62 \mathrm{kDa}$ under reducing conditions.

\section{HUVEC cultures}

HUVECs were isolated and cultured as described in [39] with some minor modifications [40]. When the cells reached confluence in the second passage, they were subcultured on fibronectincoated 24-well or 96-well plastic tissue-culture plates and grown to confluence for studies of prothrombinase activity or protein $\mathrm{C}$ activation. At confluence, the culture medium was refreshed and the cells were used within the next $24 \mathrm{~h}$.

\section{Effect of protein $\mathrm{C}$ activated in situ by locally activated prothrombin on the endothelial cell-mediated prothrombinase complex activity}

All assays were performed at $37^{\circ} \mathrm{C}$. Endothelial cells were washed three times with a $0.22 \mu \mathrm{m}$-filtered Hepes buffer containing $25 \mathrm{mM}$ Hepes, $135 \mathrm{mM} \mathrm{NaCl}, 4 \mathrm{mM} \mathrm{KCl}, 15 \mathrm{mM}$ glucose, $\mathrm{pH} 7.4$, and then washed twice with the same buffer containing $3 \mathrm{mM} \mathrm{CaCl}$ and $3 \mathrm{mg} / \mathrm{ml} \mathrm{BSA}$. In this buffer, $100 \mathrm{pM}$ factor Va and $1 \mathrm{nM}$ factor Xa were preincubated in $300 \mu \mathrm{l}$ on the endothelial cells for $10 \mathrm{~min}$ in the presence or absence of protein $\mathrm{C}$, protein $\mathrm{S}$ or other ligands, and prothrombin was added to a final concentration of $1 \mu \mathrm{M}$. The plates were shaken once per minute. After $10 \mathrm{~min}$ or at indicated time points, duplicate samples (10 $\mu$ l each) were transferred to a $96-$ well plate containing $40 \mu 1$ of $0.5 \mathrm{M}$ EDTA in Tris-buffered saline in each well to terminate the prothrombin activation. Activated prothrombin (i.e. $\alpha$-thrombin and meizothrombin) and APC were determined by measuring the rate of hydrolysis of S2238 and S2366 respectively, measured in a V-max reader (Molecular Devices Corporation, Menlo Park, CA, U.S.A.) at $405 \mathrm{~nm}$. APC was measured in triplicate in $50 \mu 1$ samples after inhibiting $\alpha$-thrombin and meizothrombin by the addition of excess hirudin ( 25 units). Dilutions of known amounts of purified thrombin and APC were used for the preparation of calibration curves.

\section{Protein $\mathbf{C}$ activation assay}

Endothelial cell monolayers were washed as described above, and protein $\mathrm{C}(65 \mathrm{nM})$ was incubated together with $\alpha$-thrombin $(30 \mathrm{nM})$ on the surface of endothelial cells at $37^{\circ} \mathrm{C}$. After $1 \mathrm{~h}$ samples were taken in triplicate, $\alpha$-thrombin was inhibited with hirudin and APC activity was determined with S2366. As a control, endothelial cells were preincubated with $200 \mathrm{nM}$ anti$\mathrm{TM}$ antibodies for $1 \mathrm{~h}$, after which protein $\mathrm{C}$ activation was performed in the presence of $200 \mathrm{nM}$ anti-TM antibodies. In addition a monoclonal antibody (RU-PC4H5) known to inhibit the activation of protein $\mathrm{C}$ was preincubated with protein $\mathrm{C}$ at a 2 -fold excess before incubation on endothelial cells. Two duplicate sets of endothelial cells were also incubated with IL-1, IL-4 and TNF in culture medium. After $24 \mathrm{~h}$ the cells were washed and one set of wells was incubated with $65 \mathrm{nM}$ protein $\mathrm{C}$ and $30 \mathrm{nM} \alpha$-thrombin. After $1 \mathrm{~h}$ two aliquots were taken from each well and APC activity was determined as described. The second set of wells was used for the prothrombinase activity assay. A mixture of $100 \mathrm{pM}$ factor $\mathrm{Va}, 1 \mathrm{nM}$ factor $\mathrm{Xa}$ and $1 \mu \mathrm{M}$ 
prothrombin was incubated on the endothelial cells. After 10 min activated prothrombin activity was determined as described.

\section{Tissue factor activity assay}

Duplicate sets of endothelial cells were incubated with IL-1, IL4 and TNF in culture medium. After $8 \mathrm{~h}$ of incubation, the cells were washed as described in the protein $\mathrm{C} /$ prothrombinase assay and incubated with $2 \mathrm{nM}$ factor VII and $160 \mathrm{nM}$ factor $\mathrm{X}$ at $37^{\circ} \mathrm{C}$. After $1 \mathrm{~h}$ duplicate samples $(50 \mu \mathrm{l})$ were analysed for factor Xa activity with the chromogenic substrate S2222.

\section{Activation of protein C by meizothrombin}

Because meizothrombin cannot be purified as a stable intermediate, owing to rapid conversion into meizothrombin des F1 by autocatalysis at $\mathrm{Arg}^{155}$, the previously described $\operatorname{Arg}^{155} \rightarrow$ Ala-prothrombin mutant was used [38]. Activation of $\operatorname{Arg}^{155} \rightarrow$ Ala-prothrombin by the purified activator from Echis coloratus venom and addition of I2581 yielded a stable meizothrombin preparation. Removal of 12581 by gel electrophoresis yielded active meizothrombin that was stable for at least $12 \mathrm{~h}$ at $0{ }^{\circ} \mathrm{C}$ [38]. Plates (96-well) containing HUVEC monolayers were washed as described and incubated with a mixture of $65 \mathrm{nM}$ protein $\mathrm{C}$ and various concentrations of $\alpha$-thrombin or $\operatorname{Arg}^{155} \rightarrow$ Ala-meizothrombin. After $60 \mathrm{~min}$ hirudin was added to the wells and APC activity was measured with the chromogenic substrate S2366.

\section{RESULTS AND DISCUSSION}

\section{APC-dependent inhibition of prothrombin activation on endothelial cells}

Under physiological conditions protein $\mathrm{C}$ is activated by $\alpha$ thrombin bound to TM that is expressed on the surface of endothelial cells in the microvasculature. We have performed studies in vitro to investigate the activation of protein $\mathrm{C}$ on endothelial cells by prothrombin activated in situ. For this purpose prothrombin was activated by $1 \mathrm{nM}$ factor $\mathrm{Xa}$ and

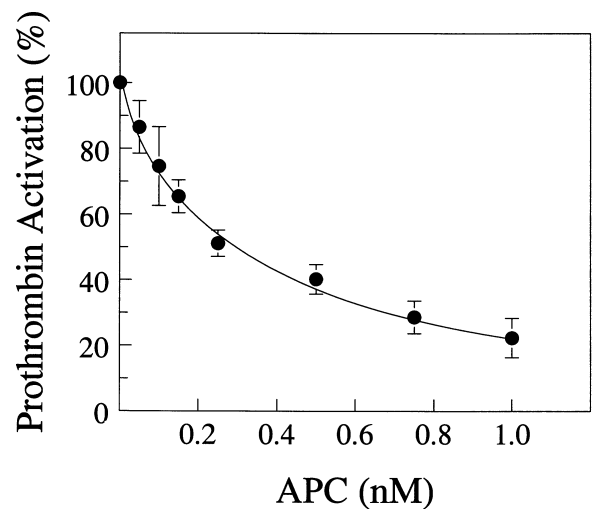

Figure 1 Inhibition of endothelial cell-mediated prothrombin activation by added APC

Factor Va and factor Xa were preincubated with endothelial cell monolayers for $10 \mathrm{~min}$ at $37^{\circ} \mathrm{C}$. Prothrombin was added together with various concentrations of APC, and after 10 min the amount of activated prothrombin was determined with the chromogenic substrate S2238 as described in the Experimental section. The final concentrations in the reaction mixture were $100 \mathrm{pM}$ factor $\mathrm{Va}, 1 \mathrm{nM}$ factor $\mathrm{Xa}, 1 \mu \mathrm{M}$ prothrombin and the amounts of APC indicated in the Figure. Points are means \pm S.D. for three measurements.

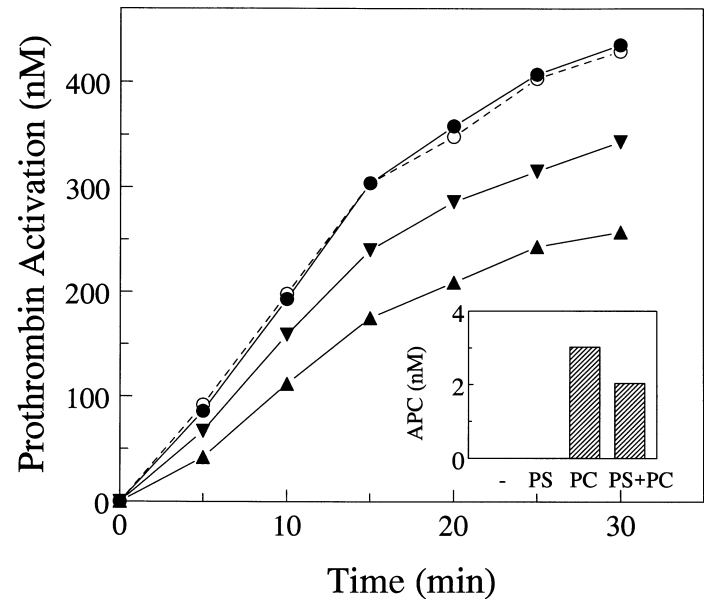

Figure 2 Inhibition of prothrombin activation by the protein C system on endothelial cells

Factor $\mathrm{Va}(100 \mathrm{pM})$ and factor $\mathrm{Xa}(1 \mathrm{nM})$ were preincubated on endothelial cell monolayers in the absence of protein $\mathrm{S}$ and protein $\mathrm{C}(\mathbf{O})$, in the presence of $10 \mathrm{nM}$ protein $\mathrm{S}(\mathrm{O}), 65 \mathrm{nM}$ protein $\mathrm{C}(\boldsymbol{\nabla})$, or $10 \mathrm{nM}$ protein $\mathrm{S}$ and $65 \mathrm{nM}$ protein $\mathrm{C}(\mathbf{\Delta})$ for 10 min at $37^{\circ} \mathrm{C}$. Prothrombin was added to a final concentration of $1 \mu \mathrm{M}$, and the amount of prothrombin activated was determined at different time points as described in the Experimental section. Inset: after 30 min of incubation, hirudin was added and the APC activity was determined in the absence of protein $S$ and protein $C(-)$, in the presence of $10 \mathrm{nM}$ protein $S(P S), 65 \mathrm{nM}$ protein $C(P C)$, or $10 \mathrm{nM}$ protein $\mathrm{S}$ and $65 \mathrm{nM}$ protein $\mathrm{C}(\mathrm{PS}+\mathrm{PC})$ as described in the Experimental section. The means from three measurements are given.

$100 \mathrm{pM}$ factor $\mathrm{Va}$ in the presence of endothelial cells. Under these conditions the prothrombinase activity on the endothelial cells was not saturated with respect to factor $\mathrm{Va}$, and the rates of prothrombin activation were thus dependent on the amount of factor Va present in the reaction mixture (results not shown). Because prothrombin activation was followed with the chromogenic substrate $\mathrm{S} 2238$, it was not possible to differentiate between $\alpha$-thrombin and meizothrombin formation, because these activation products have the same amidolytic activity [41]. Therefore throughout this paper the term 'prothrombin activation' refers to the sum of $\alpha$-thrombin and meizothrombin generation.

When APC was added with prothrombin to the endothelial cells that had been preincubated with factor Xa and Va, a dosedependent decrease in prothrombin activation with increasing concentration of APC was observed (Figure 1). At $250 \mathrm{pM} \mathrm{APC}$ the amount of prothrombin activated after 10 min was $50 \%$ of that activated in the absence of APC.

\section{Protein C activation by thrombin generated in situ}

Preincubation of factor $\mathrm{Va}$ and factor $\mathrm{Xa}$ in the presence of $3 \mathrm{mM} \mathrm{CaCl}_{2}$ with quiescent HUVECs for $10 \mathrm{~min}$ before adding prothrombin to a final concentration of $1 \mu \mathrm{M}$ resulted in the time course of prothrombin activation shown in Figure 2. When prothrombin was added to the endothelial cells together with protein $\mathrm{C}(65 \mathrm{nM})$, it was observed that prothrombin activated in situ was capable of activating protein C. After $30 \mathrm{~min}, 3 \mathrm{nM}$ APC was generated (Figure 2, inset). Moreover, the formation of APC resulted in $25 \%$ inhibition of prothrombin activation (Figure 2).

The presence of $10 \mathrm{nM}$ protein $\mathrm{S}$ alone did not inhibit prothrombin activation. However, when $10 \mathrm{nM}$ protein $\mathrm{S}$ and $65 \mathrm{nM}$ protein $\mathrm{C}$ were added together to the reaction mixture, an inhibition of the endothelial cell-mediated prothrombin activation of approx. $45 \%$ was observed after $30 \mathrm{~min}$ (Figure 2). 
Table 1 Effect of protein $S$ on the inhibition of prothrombin activation by APC generated in situ

Factor Va (100 pM) and factor Xa (1 nM) were preincubated on endothelial cell monolayers with $65 \mathrm{nM}$ protein $\mathrm{C}$ in the presence or absence of protein $\mathrm{S}$ for $10 \mathrm{~min}$ at $37^{\circ} \mathrm{C}$. Prothrombin was added to a final concentration of $1 \mu \mathrm{M}$, and the amounts of prothrombin and protein $\mathrm{C}$ activated after 10 min were determined as described in the Experimental section. The protein $\mathrm{S}$ cofactor activity for APC is expressed as a function of the amount of APC generated. The means of two duplicate measurements are given.

\begin{tabular}{llll}
\hline $\begin{array}{l}\text { [Protein S }] \\
(\mathrm{nM})\end{array}$ & $\begin{array}{l}\text { Inhibition of } \\
\text { prothrombinase (\%) }\end{array}$ & $\begin{array}{l}\text { APC generated } \\
(\mathrm{pM})\end{array}$ & Relative rate \\
\hline 0 & 23.5 & 354 & 1 \\
0.6 & 32.5 & 326 & 1.5 \\
3 & 36.8 & 277 & 2.0 \\
10 & 50.4 & 205 & 3.7 \\
\hline
\end{tabular}

Interestingly, the addition of protein $\mathrm{S}$ to the incubation mixture resulted in a $30 \%$ decrease in APC formation, owing to an extra decrease in prothrombin activation by the APC-cofactor activity of protein $\mathrm{S}$ (Figure 2, inset). In contrast with a previous study [42], we did not observe protein $\mathrm{C}$ activation by factor $\mathrm{Xa}$ in the presence of TM on endothelial cells (results not shown).

Studies in vitro showed that protein $\mathrm{S}$ is a cofactor with moderate activity that enhances factor Va inactivation by APC only 2-fold [34,43-45]. We have investigated the effect of protein $\mathrm{S}$ on the negative feedback reaction of APC on endothelial cellmediated prothrombin activation. Increasing amounts of protein $\mathrm{S}$ in the presence of a fixed concentration of protein $\mathrm{C}$ resulted in a concentration-dependent inhibition of prothrombin activation on endothelial cells (Table 1). Together with the inhibition of prothrombin activation, the amount of APC generated decreased gradually. In the absence of protein $\mathrm{C}, 10 \mathrm{nM}$ protein $\mathrm{S}$ did not affect prothrombin activation. This confirms an earlier report in which it was shown that higher concentrations of protein S are required for APC-independent inhibition of prothrombin activation [17].

Because the APC concentration decreased when increasing amounts of protein $\mathrm{S}$ were present, the protein $\mathrm{S}$ cofactor activity for APC was expressed as a function of the concentration of generated APC (Table 1, Relative rate). A maximal 3-4-fold amplification of the anticoagulant activity of APC was observed at $10 \mathrm{nM}$ protein $\mathrm{S}$. This increased APC-cofactor activity of protein $\mathrm{S}$ (compared with the 2-fold stimulation reported previously) supports earlier observations that factor $\mathrm{Va}$ is protected

Table 2 Characterization of protein C activation by exogenous $\alpha$-thrombin on HUVECS

Protein C (65 nM) and $\alpha$-thrombin $(28 \mathrm{nM})$ were incubated on HUVECs for $1 \mathrm{~h}$ at $37^{\circ} \mathrm{C}$. Protein $\mathrm{C}$ activation was determined as described in the Experimental section. Abbreviation: PMA, phorbol 12-myristate 13-acetate.

\begin{tabular}{lcl}
\hline Effector & $\begin{array}{l}\text { Protein C activation } \\
(\% \pm \text { S.D. })\end{array}$ & $\begin{array}{l}\text { Specific activation } \\
(\% \text { inhibition })\end{array}$ \\
\hline None & 100 & - \\
Anti-TM $(200 \mathrm{nM}, n=3)$ & $48 \pm 4$ & 66 \\
PMA $(20 \mathrm{ng} / \mathrm{ml}, n=2)$ & 256 & - \\
RU-PC4H5 $(130 \mathrm{nM}, n=3)$ & $7 \pm 5$ & $>90$ \\
No HUVECs $(n=3)$ & $21 \pm 7$ & - \\
\hline
\end{tabular}

by factor Xa from inactivation by APC [4,46-48] and that protein $\mathrm{S}$ counteracts this protective effect of factor Xa $[14,43]$.

The presence of $10 \mathrm{nM}$ thrombin-cleaved protein $\mathrm{S}$, or $10 \mathrm{nM}$ protein $\mathrm{S}$ complexed with $\mathrm{C} 4 \mathrm{~b}$-binding protein in reaction mixtures containing endothelial cells, prothrombin, factor $\mathrm{Xa}$, factor $\mathrm{Va}$ and protein $\mathrm{C}$, affected neither prothrombin activation nor APC generation (results not shown).

\section{Protein $\mathrm{C}$ activation by exogenously added $\alpha$-thrombin}

The activation of protein $\mathrm{C}$ is regulated by the expression of TM on the endothelial cell surface. Varying the amount of TM expressed on the endothelial cell surface will influence the activation of the protein $\mathrm{C}$ pathway. The TM-dependence of the protein $\mathrm{C}$ activation by exogenous $\alpha$-thrombin was investigated. Protein $\mathrm{C}$ activation by $\alpha$-thrombin on the surface of endothelial cells was more than $75 \%$ dependent on the presence of endothelial cells (Table 2). When protein $C$ was preincubated with a 2-fold excess of anti-protein C antibody RU-PC4H5, less than $10 \%$ protein $\mathrm{C}$ activation was observed. This observation shows the specificity of the hydrolysis of S2366 by generated APC. Incubation of endothelial cells with $20 \mathrm{ng} / \mathrm{ml}$ PMA for $48 \mathrm{~h}$ leads to an up-regulation of TM activity on endothelial cells to $256 \%$, which is in agreement with an earlier study [49]. Treatment of endothelial cells with goat anti-(rabbit TM) antibodies resulted in a $50 \%$ decrease in total protein $\mathrm{C}$ activation, owing to crossreactivity of the antibodies with human TM. Corrected for the TM-independent protein C activation in wells without endothelial cells (background, 21\%), the antibodies inhibited the TMdependent protein $\mathrm{C}$ activation by $66 \%$ (Table 2 ). These results suggest that the protein $\mathrm{C}$ activation on HUVECs by exogenously added $\alpha$-thrombin is dependent on the amount of TM expressed on the HUVEC surface.

\section{Influence of cytokines on endothelial cell-mediated protein C, factor $X$ and prothrombin activation}

To study the effect of the down-regulation of TM on the activation of the protein $\mathrm{C}$ pathway, endothelial cells were incubated for 8 and $24 \mathrm{~h}$ with IL-1, IL-4 and TNF. After $8 \mathrm{~h}$, tissue factor activity was determined as a control experiment for the procoagulant cytokine stimulus of TNF and IL-1. Factor VII and factor $\mathrm{X}$ were added, and factor Xa activity generated by the tissue factor-factor VIIa complex was determined after $1 \mathrm{~h}$. It was observed that TNF and IL-1 induced a dose-dependent generation of factor Xa by the tissue factor-factor VIIa complex on endothelial cells, which is explained by a dose-dependent increase of tissue factor expression by TNF and IL-1 on the HUVEC surface (Figure 3A). Because this experiment was performed with an excess of factor VII $(2 \mathrm{nM})$ and factor $\mathrm{X}$ $(160 \mathrm{nM})$, the rate of activation of factor $\mathrm{X}$ was limited by the amount of tissue factor expressed on the HUVEC surface (results not shown). After $24 \mathrm{~h}$ of stimulation, the endothelial cells were assayed for TM activity and for their ability to support prothrombinase complex activity. Both IL-1 and TNF decreased the protein $\mathrm{C}$ activation on the endothelial cell surface in a dosedependent manner, with $50 \%$ inhibition at 8 pM TNF or $100 \mathrm{pM}$ IL-1 respectively (Figure 3B). A maximal down-regulation of protein $\mathrm{C}$ activation by $70 \%$ was obtained at $50 \mathrm{pM}$ TNF or 500 pM IL-1 respectively. As a control, IL-4, which has no known effect on TM down-regulation or tissue factor upregulation, was added (Figure 3 ). None of the cytokine stimulations had an effect on the ability of HUVECs to support prothrombinase activity (Figure 3C). Counteraction of the dosedependent TNF-induced down-regulation of TM expression by 

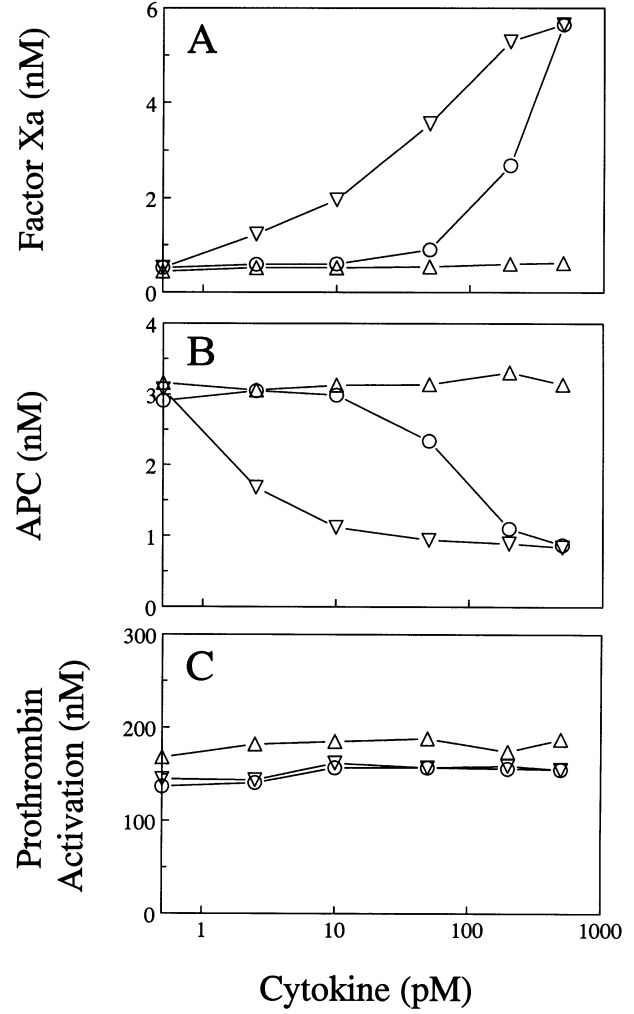

Figure 3 Regulation of the endothelial cell-mediated activation of protein $C$ and factor $X$ by TNF, IL-1 and IL-4

Endothelial cells were incubated with TNF $(\nabla), I L-1(O)$ and IL-4 $(\triangle)$ at $37^{\circ} \mathrm{C}$. After $8 \mathrm{~h}$ of stimulation, tissue factor activity on endothelial cells was determined as described in the Experimental section (A). After $24 \mathrm{~h}$ of stimulation, TM activity (B) and the ability of endothelial cells to support prothrombin activation by the prothrombinase complex (C) were investigated as described in the Experimental section. The means from duplicate experiments are shown.

Table 3 Effect of stimulation of HUVECs on the inactivation of prothrombinase activity by APC generated by prothrombin activated in situ

Factor $\mathrm{Va}(100 \mathrm{pM})$ and factor $\mathrm{Xa}(1 \mathrm{nM})$ were preincubated on endothelial cell monolayers in the presence of protein $\mathrm{C}(65 \mathrm{nM})$ for $10 \mathrm{~min}$ at $37^{\circ} \mathrm{C}$. Prothrombin was added to a final concentration of $1 \mu \mathrm{M}$ and after 10 min prothrombin activation and APC generation were determined as described in the Experimental section. The means \pm S.D. for four measurements are given.

\begin{tabular}{lllr}
\hline & & \multicolumn{2}{l}{ APC formed } \\
\cline { 3 - 4 } Effector & $\begin{array}{l}\text { Prothrombin activation } \\
\text { (\% inhibition })\end{array}$ & $(\mathrm{pM})$ & $(\%)$ \\
\hline None & $31 \pm 6$ & $374 \pm 45$ & 100 \\
$50 \mathrm{pM}$ TNF $(24 \mathrm{~h})$ & $24 \pm 4$ & $237 \pm 46$ & 64 \\
$500 \mathrm{pM} \mathrm{IL-1}(24 \mathrm{~h})$ & $26 \pm 6$ & $327 \pm 73$ & 87 \\
$200 \mathrm{nM}$ anti-TM (1 h) & $21 \pm 2$ & $251 \pm 37$ & 67 \\
& & & \\
\end{tabular}

high concentrations of IL-4 (500 pM), which has previously been reported [50], was not observed (results not shown).

\section{Regulation of protein C activation by prothrombin activated in situ}

The addition of $65 \mathrm{nM}$ protein $\mathrm{C}$ to the prothrombinase complex on the surface of HUVECs resulted in a $31 \%$ decrease in prothrombin activation by the negative feedback on pro- thrombinase activity by locally generated APC (Table 3). We conclude that this inhibition of prothrombinase activity was a result of the generation of APC by TM-thrombin/meizothrombin complex generated in situ and the subsequent inactivation of factor Va by APC.

We investigated the effect of the regulation of TM expression on the activation of protein $\mathrm{C}$ by locally generated prothrombin activation products. When endothelial cells were incubated with $50 \mathrm{pM}$ TNF for $24 \mathrm{~h}$, a $24 \%$ inhibition of prothrombinase activity was observed. The APC level generated during incubation was $237 \mathrm{pM}(64 \%$ of control; Table 2). The decrease in prothrombinase inhibition and the level of APC generated by prothrombin activated in situ was surprisingly high in view of the results observed in Figure 3(B). On the same TNF-stimulated endothelial cells the protein $\mathrm{C}$ activation by exogenously added $\alpha$-thrombin decreased to $31 \%$ of the control. Stimulation of endothelial cells with 500 pM IL-1 resulted in a $26 \%$ inhibition of prothrombinase activity with a protein C activation of $327 \mathrm{pM}$ ( $87 \%$ of control; Table 3 ). These values are similar to those obtained with the untreated endothelial cells. Again, a surprising difference was found from the results in Figure 3(B), where the same IL-1 stimulation resulted in an inhibition of APC generation to $30 \%$ of the control. Incubation with $200 \mathrm{nM}$ anti-TM antibodies for $1 \mathrm{~h}$ showed that the inhibition of prothrombinase activity by APC formed by prothrombin activated in situ was still dependent on TM. However, the decrease in APC generation to $67 \%$ compared with control cells was less than observed on antiTM-treated endothelial cells where the activation of protein $\mathrm{C}$ by external added $\alpha$-thrombin was studied ( $48 \%$ of control; Table 2 ). This suggests that there is a difference in the rate of activation of protein $\mathrm{C}$ on endothelial cells by added $\alpha$-thrombin and by prothrombin activation products generated in situ.

\section{Activation of protein C by $\alpha$-thrombin and Arg $^{155} \rightarrow$ Ala- meizothrombin}

Our results suggested that the activation of protein $\mathrm{C}$ on HUVECs by locally generated prothrombin activation products was more effective than by exogenously added $\alpha$-thrombin. The difference might be explained by the presence of meizothrombin formed during the activation of prothrombin in situ. Previous studies in our laboratories showed that meizothrombin is generated as an active intermediate during prothrombin activation in the initial phase of prothrombinase activity on phospholipid vesicles [41] and on HUVECs [51]. Although it was reported that in the presence of endothelial cells meizothrombin was not a better activator of protein $\mathrm{C}$ than $\alpha$-thrombin [52] and that activesite-mutated meizothrombin $\left(\mathrm{Ser}^{205} \rightarrow\right.$ Ala) did not bind to TM [53], it was still suggested that meizothrombin generation is targeted towards an anticoagulant function such as protein $\mathrm{C}$ activation [52], because of its poor procoagulant activities [41,52]. Therefore, in our system with HUVECs, the possibility that meizothrombin is a better activator of protein $\mathrm{C}$ had to be elucidated. Because meizothrombin cannot be purified as a stable intermediate, owing to rapid degradation into meizothrombin des F1 by autocatalysis at $\operatorname{Arg}^{155}$, we used $\operatorname{Arg}^{155} \rightarrow$ Ala-meizothrombin, which was derived from recombinant prothrombin mutated at position 155 [38]. To compare the efficiencies of $\alpha$ thrombin and $\operatorname{Arg}^{155} \rightarrow$ Ala-meizothrombin in the activation of protein $\mathrm{C}$, the following control experiments were performed: $\alpha$ thrombin as well as $\operatorname{Arg}^{155} \rightarrow$ Ala-meizothrombin was inhibited by $99 \%$ after incubation with a 10-fold excess of hirudin for $5 \mathrm{~min}$. In the presence or absence of 1,2-dioleoyl-sn-glycero-3phosphoserine/1,2-dioleoyl-sn-glycero-3-phosphocholine (1:9, 


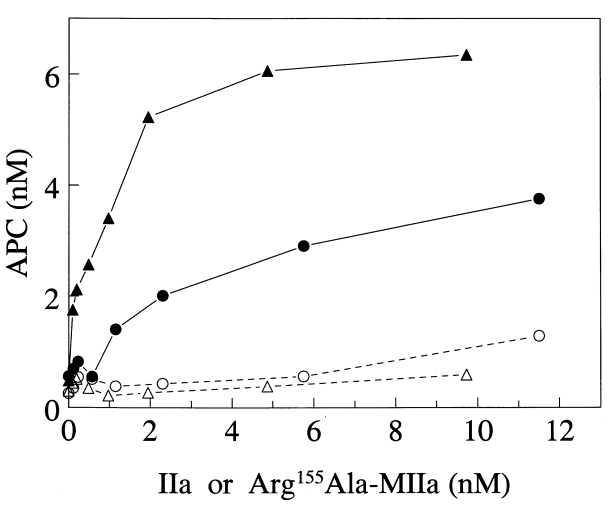

Figure 4 Activation of protein C by $\alpha$-thrombin (Ila) and $\mathrm{Arg}^{155} \rightarrow$ Alameizothrombin (MIla) on the surface of HUVECs

Endothelial cells were incubated with $65 \mathrm{nM}$ protein $\mathrm{C}$ and different concentrations of $\alpha$ thrombin and $\mathrm{Arg}^{155} \rightarrow$ Ala-meizothrombin as described in the Experimental section. After $1 \mathrm{~h}$ $\alpha$-thrombin or $\operatorname{Arg}^{155} \rightarrow$ Ala-meizothrombin activity was inhibited by hirudin and the amount of APC formed was determined with chromogenic substrate S2366. Activation of protein C is plotted against the concentration of $\alpha$-thrombin $(\mathbf{O}, \bigcirc)$ and $\operatorname{Arg}^{155} \rightarrow$ Ala-meizothrombin $(\boldsymbol{\Delta}, \triangle$ ) in the presence (filled symbols) or absence (open symbols) of endothelial cells. The means from duplicate experiments are shown.

$\mathrm{w} / \mathrm{w})$ vesicles $(50 \mu \mathrm{M})$, activation of protein $\mathrm{C}(0.5 \mu \mathrm{M})$ by $\alpha$-thrombin or $\operatorname{Arg}^{155} \rightarrow$ Ala-meizothrombin $(5 \mathrm{nM})$ was not observed (results not shown).

Plates (96-well) containing HUVEC monolayers were washed as described and incubated with a mixture of $65 \mathrm{nM}$ protein $\mathrm{C}$ and various concentrations of $\alpha$-thrombin or $\operatorname{Arg}^{155} \rightarrow$ Alameizothrombin. After 60 min hirudin was added to inhibit $\alpha$ thrombin or $\operatorname{Arg}^{155} \rightarrow$ Ala-meizothrombin, and the amount of APC formed was determined with the chromogenic substrate S2366.

Figure 4 shows that $\operatorname{Arg}^{155} \rightarrow$ Ala-meizothrombin is a better activator of protein $\mathrm{C}$ than is $\alpha$-thrombin. Because at low thrombin and meizothrombin concentrations 6-fold more $\alpha$-thrombin was required for protein $\mathrm{C}$ activation, we conclude that meizothrombin is at least 6 -fold more effective in activating protein $C$ than is $\alpha$-thrombin. This was confirmed by a recent report from Côté et al. [54] in which a similar stimulation of TMdependent protein $\mathrm{C}$ activation in the presence of phospholipid by a triple mutant of meizothrombin was observed (Arg ${ }^{155} \rightarrow$ Ala, $\operatorname{Arg}^{271} \rightarrow$ Ala and $\mathrm{Arg}^{284} \rightarrow$ Ala).

There seems to be no relation between the APC generation and the level of $\alpha$-thrombin or activated prothrombin present in the reaction mixtures (Figures 2-4 and Tables 1-3). Because the average concentrations of APC generated per hour in these experiments were approximately the same $(3.9 \pm 1.8 \mathrm{nM} \mathrm{APC})$, we conclude that APC generation was not dependent on the $\alpha$ thrombin/activated prothrombin concentrations but was limited by the amount of TM expressed on the surface of endothelial cells. However, at low concentrations of $\alpha$-thrombin and meizothrombin (0-1 nM), APC formation became independent of TM expression and seemed to be limited by the amount of activator. Under these conditions meizothrombin is at least a 6-fold better activator of protein $\mathrm{C}$ than $\alpha$-thrombin (Figure 4).

This shows that the contribution of meizothrombin to the activation of protein $\mathrm{C}$ is particularly important in the early phase of prothrombin activation, because under these conditions the total concentration of activated prothrombin is low and the relative concentration of meizothrombin is high [41]. Because no protein $\mathrm{C}$ activation by $\mathrm{Arg}^{155} \rightarrow$ Ala-meizothrombin was observed when endothelial cells were replaced by phospholipid vesicles, we conclude that APC generation by meizothrombin on endothelial cells is TM-dependent. The fact that meizothrombin is a better protein $\mathrm{C}$ activator than thrombin is indicative of a contribution of the $\gamma$-carboxyglutamic acid-containing fragment 1 region of meizothrombin in the formation of the endothelial cell TM-meizothrombin complex. This could be due to a calciumdependent interaction of the fragment 1 region either with TM or with phospholipids in the endothelial cell surface.

It remains to be elucidated whether the endothelial cell protein $\mathrm{C}$ receptor [32] also plays a role in the regulation of protein $\mathrm{C}$ activation by $\alpha$-thrombin or meizothrombin on endothelial cells.

We thank Dr. W. Kisiel for the donation of the human $\alpha$-thrombin, purified $A$. contortrix contortrix snake venom and anti-( $A$. contortrix contortrix snake venom) antibodies, and Dr. Aarden for the donation of IL-1. This work was supported in part by grant no. 900-512-130 from the Dutch Foundation for Medical Research.

\section{REFERENCES}

1 Esmon, C. T. (1993) Thromb. Haemost. 70, 29-35

2 Kisiel, W., Canfield, W. M., Ericsson, L. H. and Davie, E. W. (1977) Biochemistry 16, 5824-5831

3 Kisiel, W. (1979) J. Clin. Invest. 64, 761-769

4 Walker, F. J., Sexton, P. W. and Esmon, C. T. (1979) Biochim. Biophys. Acta 571, 333-342

5 Vehar, G. A. and Davie, E. W. (1980) Biochemistry 19, 401-410

6 Marlar, R. A., Kleiss, A. J. and Griffin, J. H. (1982) Blood 59, 1067-1072

7 Fulcher, C. A., Gardiner, J. H., Griffin, J. H. and Zimmerman, T. S. (1984) Blood 63, 486-489

8 Kalafatis, M., Rand, M. D. and Mann, K. G. (1994) J. Biol. Chem. 269 31869-31880

9 Kalafatis, M., Bertina, R. M., Rand, M. D. and Mann, K. G. (1995) J. Biol. Chem. 270, 4053-4057

10 Nicolaes, G. A. F., Tans, G., Thomassen, M. C. L. G.D., Hemker, H. C., Pabringer, I., Varadi, K., Schwarz, H. P. and Rosing, J. (1995) J. Biol. Chem. 270, 21158-21166

11 Eaton, D., Rodriguez, H. and Vehar, G. A. (1986) Biochemistry 25, 505-512

12 Fay, P. J., Smudzin, T. M. and Walker, F. J. (1992) J. Biol. Chem. 266 20139-20145

13 Walker, F. J. (1981) J. Biol. Chem. 256, 11128-11131

14 Rosing, J., Hoekema, L., Nicolaes, G., Thomassen, M. C. L. G.D., Hemker, H. C., Varadi, K., Schwarz, H. P. and Tans, G. (1995) J. Biol. Chem. 270, 27852-27858

15 Heeb, M. J., Mesters, R. M., Tans, G., Rosing, J. and Griffin, J. H. (1993) J. Biol. Chem. 268, 2872-2877

16 Heeb, M. J., Rosing, J., Bakker, H. M., Fernández, J. A., Tans, G. and Griffin, J. H. (1994) Proc. Natl. Acad. Sci. U.S.A. 91, 2728-2732

17 Hackeng, T. M., van 't Veer, C., Meijers, J. C. M. and Bouma, B. N. (1994) J. Biol. Chem. 269, 21051-21058

18 van 't Veer, C., Hackeng, T. M., Biesbroek, D., Sixma, J. J. and Bouma, B. N. (1994) Blood 85, 1815-1821

19 Gladson, C. L., Scharrer, I., Hach, V., Beck, K. H. and Griffin, J. H. (1988) Thromb. Haemost. 59, 18-22

20 Nawroth, P. P. and Stern, D. M. (1986) J. Exp. Med. 163, 740-745

21 Nawroth, P. P., Handley, D. A., Esmon, C. T. and Stern, D. M. (1986) Proc. Natl. Acad. Sci. U.S.A. 83, 3460-3464

22 Moore, K. L., Andreoli, S. P., Esmon, N. L., Esmon, C. T. and Bang, N. U. (1987) J. Clin. Invest. 79, 124-130

23 Moore, K. L., Esmon, C. T. and Esmon, N. L. (1989) Blood 73, 159-165

24 Conway, E. M. and Rosenberg, R. D. (1988) Mol. Cell. Biol. 8, 5588-5592

25 Scarpati, E. M. and Sadler, E. M. (1989) J. Biol. Chem. 264, 20705-20713

26 Taylor, F. B., Chang, A. C. K., Esmon, C. T., D‘Angelo, A., Vigano-D‘Angelo, S. and Blick, K. (1987) J. Clin. Invest. 79, 918-925

27 Esmon, C. T., Taylor, F. B. and Snow, T. R. (1991) Thromb. Haemost. 66, 160-165

28 Taylor, F. B., Chang, A. C. K., Ferrell, G., Mather, T., Catlett, R., Blick, K. and Esmon, C. T. (1991) Blood 78, 357-363

29 Coalson, J. J., Benjamin, B., Archer, L. T., Beller, B., Gilliam, C. L., Taylor, F. B. and Hinshaw, L. B. (1978) Circ. Shock 5, 423-437

30 Warr, T. A., Rao, V. M. and Rapaport, S. I. (1990) Blood 75, 1481-1489

31 Taylor, F. B., Chang, A. C. K., Peer, G. T., Mather, T., Blick, K., Catlett, R., Lockhart, M. S. and Esmon, C. T. (1991) Blood 78, 364-368

32 Fukudome, K. and Esmon, C. T. (1994) J. Biol. Chem. 269, 26486-26491 
33 Koedam, J. A., Meijers, J. C. M., Sixma, J. J. and Bouma, B. N. (1988) J. Clin. Invest. 82, 1236-1243

34 Hackeng, T. M., Hessing, M., van 't Veer, C., Meijer-Huizinga, F., Meijers, J. C. M., de Groot, P. G., van Mourik, J. A. and Bouma, B. N. (1993) J. Biol. Chem. 268 3993-4000

35 Hessing, M., Kanters, D., Hackeng, T. M. and Bouma, B. N. (1990) Thromb. Haemost. 64, 245-250

36 Kane, W. H. and Majerus, P. W. (1981) J. Biol. Chem. 256, 1002-1007

37 van 't Veer, C., Hackeng, T. M., Delahaye, C., Sixma, J. J. and Bouma, B. N. (1994) Blood 84, 1132-1142

38 Tans, G., Nicolaes, G. A. F., Thomassen, M. C. L. G. D., Hemker, H. C., Zonneveld, A. J., Pannekoek, H. and Rosing, J. (1994) J. Biol. Chem. 269, 15969-15972

39 Jaffe, E. A., Nachman, R. L., Becker, C. G. and Minick, R. (1973) J. Clin. Invest. 52 $2745-2756$

40 Willems, C., Astaldi, G. C. B., de Groot, P. G., Janssen, M. C., Gonsalvez, M. D., Zeijlemaker, W. P., van Mourik, J. A. and van Aken, W. G. (1982) Exp. Cell. Res. 139, 191-200

41 Rosing, J., Zwaal, R. F. A. and Tans, G. (1986) J. Biol. Chem. 261, 4224-4228

42 Haley, P. E., Doyle, M. E. and Mann, K. G. (1989) J. Biol. Chem. 264, 16303-16310
43 Solymoss, S., Tucker, M. M. and Tracy, P. B. (1988) J. Biol. Chem. 263 , 14884-14890

44 Tans, G., Rosing, J., Thomassen, M. C. L. G. D., Heeb, M. J., Zwaal, R. F. A. and Griffin, J. H. (1991) Blood 77, 2641-2648

45 Bakker, H. M., Tans, G., Janssen-Claessen, T., Thomassen, M. C. L. G. D., Hemker, H. C., Griffin, J. H. and Rosing, J. (1992) Eur. J. Biochem. 208, 171-178

46 Comp, P. C. and Esmon, C. T. (1979) Blood 54, 1272-1281

47 Dahlbäck, B. and Stenflo, J. (1980) Eur. J. Biochem. 107, 331-335

48 Nesheim, M. E., Canfield, W. M., Kisiel, W. and Mann, K. G. (1982) J. Biol. Chem. 257, 1443-1447

49 Hirokawa, K. and Aoki, N. (1990) Biochem. J. 108, 839-845

50 Kapiotis, S., Besemer, J., Bevec, D., Valent, P., Bettelheim, P., Lechner, K. and Speiser, W. (1991) Blood 78, 410-415

51 Tijburg, P. N. M., van Heerde, W. L., Leenhouts, H. M., Hessing, M., Bouma, B. N. and de Groot, P. G. (1990) J. Biol. Chem. 266, 4017-4022

52 Doyle, M. F. and Mann, K. G. (1990) J. Biol. Chem. 265, 10693-10701

53 Wu, Q., Tsiang, M., Lentz, S. R. and Sadler, J. E. (1992) J. Biol. Chem. 267, 7083-7088

54 Côté, H. C. F., Baizar, L., Stevens, W. K., Samis, J. A., Morser, J., Nesheim, M. E. and MacGillivray, R. T. A. (1995) Blood 86, 72a

Received 29 April 1996/19 June 1996; accepted 21 June 1996 